\title{
Seasonal Changes in Nitrate Uptake Efficiency in Young Potted Citrus Trees
}

\author{
Belén Martínez-Alcántara ${ }^{1}$, Ana Quiñones ${ }^{1}$, Eduardo Primo-Millo ${ }^{1} \&$ Francisco Legaz $^{1}$ \\ ${ }^{1}$ Instituto Valenciano de Investigaciones Agrarias, Spain \\ Correspondence: Belén Martínez-Alcántara, Instituto Valenciano de Investigaciones Agrarias, Ctra. \\ Moncada-Náquera km. 4.5, Apdo. Oficial 46113 Moncada (Valencia), Spain. Tel: 34-963-424-000. E-mail: \\ martinez_belalc@gva.es
}

Received: February 8, 2012 Accepted: March 5, 2012 Online Published: June 29, 2012

doi:10.5539/jas.v4n8p11

URL: http://dx.doi.org/10.5539/jas.v4n8p11

This study was founded by the Instituto Nacional de Investigaciones Agrarias (RTA 04-064).

\begin{abstract}
Fertilizer isotope labelling $\left({ }^{15} \mathrm{~N}\right)$ of young Lane Late potted orange trees with differential $\mathrm{N}$ rates at three phenological periods (end of flowering, fruit set and fruit growth) was used to determine patterns of $\mathrm{N}$ uptake response and $\mathrm{N}$ efficiency (NUE) along the growing cycle. In a first experiment trees were fed with a saturating $\mathrm{N}$ solution in order to determine seasonal variations in $\mathrm{N}$ requirements. The second experiment tested four $\mathrm{N}$ rates which were equal to $\left(\mathrm{N}_{1}\right)$, two $\left(\mathrm{N}_{2}\right)$, three $\left(\mathrm{N}_{3}\right)$ and four-fold $\left(\mathrm{N}_{4}\right)$ the $\mathrm{N}$ requirements at each period. Increasing $\mathrm{N}$ rate diminished NUE being the decrease more acute at flowering as a consequence of the lower response in $\mathrm{N}$ uptake to increased $\mathrm{N}$ supply in this period. Theoretical NUE corresponding to a fertilizer rate that fulfills plant requirements in each period was calculated, being highest at the end of fruit set period $(72 \%)$, which contrasted with the value obtained for flowering $(28 \%)$, when potential nitrogen leaching reached therefore its maximum (71\%).
\end{abstract}

Keywords: $\mathrm{N}$ uptake, ${ }^{15} \mathrm{~N}, \mathrm{~N}$ recovery

\section{Introduction}

Efficient use of fertilizer $\mathrm{N}$ has become a first-order concern in modern citrus production due to nitrate contamination of ground and surface waters. Excessive $\mathrm{N}$ fertilizer rates typically increase $\mathrm{N}$ leaching and may also result in ground water contamination (Alva \& Paramasivam, 1998; McNeal et al., 1994). It has been estimated that $50-70 \%$ of the nitrogen provided to the soil is lost (Hodge et al., 2000), which contributes to $50-80 \%$ of the total $\mathrm{N}$ delivered to groundwater in most countries of the European Union (EEA, 2003). Interest in improving utilization of fertilizer $\mathrm{N}$ by citrus has been particularly widespread in Mediterranean areas, were citrus cultivation predominates, and most wells show nitrate concentrations clearly above the limit of the World Health Organization (WHO, 2004).

The use of nitrogen by plants involves several steps, including uptake, assimilation, translocation, recycling and remobilization (Masclaux-Daubresse et al., 2010). Nitrogen uptake efficiency (NUE) can be defined as the percentage of applied $\mathrm{N}$ taken up by plants (Maust and Williamson, 1994). Several factors affect fertilizer N uptake efficiency, including plant demand for $\mathrm{N}$ (Weinbaum et al., 1992), the rate, timing of application and water management (Lea-Cox et al., 2001; Syvertsen \& Smith, 1996; Alva et al., 1998 and 2003; Quiñones et al., 2003 and 2005), the form of N applied and soil type (Martínez et al., 2002; Quiñones et al., 2011). Other factors inherent to the plant, as size and depth of rot system, that determine the plant ability to intercept $\mathrm{N}$ before leached below the rootzone (Scholberg et al., 2002), can also influence NUE. Research efforts during the past decades have focused on the identification of several management and environmental factors that improve NUE. As a result of these studies, current citrus best management practices recommend fertilizer applications based on leaf tissue and soil analysis, instead of routine applications (Boman et al., 2004), reducing $\mathrm{N}$ application rates (Lea-Cox \& Syvertsen, 1996), avoiding over-fertilization and subsequent losses of nutrients in drainage water. Moreover, an appropriate timing which maintains the supply of nutrients over the growing cycle and avoids applications during the rainy season (Tucker et al., 1995; Martínez-Alcántara et al., 2011), constitutes one of the most relevant strategies in diminishing nitrate leaching and thus improving NUE. 
It is widely assumed that $\mathrm{N}$ accumulation in tree in an overall cycle reflects its $\mathrm{N}$ demand (Alva et al., 2006). Therefore, in previous studies total tree $\mathrm{N}$ uptake has been evaluated at the end of a complete growth cycle by means of $15 \mathrm{~N}$ labeled fertilizers (Kato et al., 1981; Syvertsen \& Smith, 1996). The use of destructive sampling of whole trees at the end of the cycle, a hard and time-consuming task, has been a valuable key to determine total uptake by citrus trees, since differences in tissue sample analyses do not necessarily reflect changes in whole tree nutrient content. However, total tree $\mathrm{N}$ uptake, and thus NUE, calculated as a single value including the overall cycle, rather than at several different growth stages, may not give a realistic picture of the $\mathrm{N}$ dynamics along the growing season. According to Stassen et al. (1999) the seasonal pattern of $\mathrm{N}$ uptake can be used for scheduling the timing and rate of $\mathrm{N}$ applications. In this way, most efficient applications are therefore achieved, when synchronized with tree $\mathrm{N}$ demand. Weinbaum et al. (2001) suggested that the sequential excavation of trees coupled with biomass determinations and nutrient analysis is the only method that can reliably indicate the seasonal patterns of tree nutrient uptake. In previous studies $\mathrm{N}$ uptake and distribution patterns in young containerized citrus has been evaluated at different stages of the growing season (Legaz et al., 1982; Martínez-Alcántara et al., 2012; Quiñones et al., 2011). In these trees, seasonal variations in N uptake occur, with the uptake appearing to be highest during periods of active shoot growth (Maust \& Williamson, 1994; Menino et al., 2007). Nevertheless, other physiologically important stages may be identified and used as selection criteria to evaluate different $\mathrm{N}$ management strategies. Also, there is a lack of information about the changes in NUE along the different phenological stages from flowering to harvest coupled to the effect of different $\mathrm{N}$ rates on plant uptake. In this context, the authors put forward the hypothesis that the growth stage of plants at the time of fertilizer application also determines NUE. The questions assessed by this research were: i) evaluate how fertilizer NUE changes according to different phenological stages and $\mathrm{N}$ rates and ii) estimate the NUE characteristic of each period.

\section{Materials and Methods}

\subsection{Plant Material}

Four-year-old Lane Late navel orange trees (Citrus sinensis (L.) Osbeck), grafted on Carrizo citrange rootstock, were grown individually in containers (internal upper diameter of $50 \mathrm{~cm}$ and $60 \mathrm{~cm}$ height) of about $120 \mathrm{~L}$, containing a loamy soil ( $45 \%$ sand, $36 \%$ silt, $19 \%$ clay; $27 \% \mathrm{CaCO}_{3}$ and $\mathrm{pH} 8.3$ ). The containers were arranged outdoors on benches under polycarbonate shelter to exclude rain, in the IVIA experimental field (Moncada, Valencia, Spain; $39^{\circ} 32^{\prime} \mathrm{N}, 0^{\circ} 23^{\prime} \mathrm{W}$ ). In order to evaluate the seasonal evolution of NUE throughout a growth cycle, three phenological periods were established, i) 15th January-15th April (from the beginning of bud development to full flowering), ii) 15th April-15th July (from full flowering to the end of fruit set) and iii) 15th July-15th October (from the end of fruit set to the beginning of fruit ripening). These periods, hereinafter called flowering, fruit set and fruit growth, correspond to the periods comprehended between the growth stages 0 to 65 , 65 to 74 and 74 to 85, according to the extended BBCH scale (Hack et al., 1992) and its adaptation for citrus trees (Agustí et al., 1997).

In the first year of the assay (2005), and with the aim of determining the nitrogen needs during the three phenological development periods (experiment 1), twenty-four trees were grown under saturating $\mathrm{N}$ supply for a whole cycle. Trees were fertigated with a nutrient solution containing $200 \mathrm{mg} \mathrm{N} \mathrm{L}^{-1}$, supplied as $\mathrm{KNO}_{3}$ and $\mathrm{Ca}\left(\mathrm{NO}_{3}\right)_{2}$. Other macro and micronutrients were supplied in the nutrient solution $(0.24 \mathrm{mM} \mathrm{P}, 0.49 \mathrm{mM} \mathrm{Mg}, 0.56$ $\mathrm{mM} \mathrm{S}, 30 \mu \mathrm{M} \mathrm{Fe}, 10 \mu \mathrm{M} \mathrm{Mn}$ and $10 \mu \mathrm{M} \mathrm{Zn}$, which were provided as $\mathrm{H}_{3} \mathrm{PO}_{4}, \mathrm{MgSO}_{4}, \mathrm{Fe}-\mathrm{EDDHA}, \mathrm{MnSO}_{4}$ and $\mathrm{ZnSO}_{4}$ ). Before $\mathrm{N}$ supply (dormancy) and at the end of each phenological period, six trees were destructively harvested to determine their $\mathrm{N}$ content; differences between consecutive harvests constituted the $\mathrm{N}$ uptake within each period.

In the next growth cycle (2006), seventy-eight uniformly-sized trees, with similar characteristics to those of the previous year (age, height and canopy diameter), were fertilized with four $\mathrm{N}$ rates in order to determine seasonal changes in NUE (experiment 2). At the beginning of this second assay six trees were harvested to determine the initial $\mathrm{N}$ status. In each phenological period (flowering, fruit set, fruit growth) twenty-four trees were fertilized with four ${ }^{15} \mathrm{~N}$ labeled rates (six trees each); $\mathrm{N}_{1}$ equals tree $\mathrm{N}$ uptake in each period, calculated in the prior assay, while $\mathrm{N}_{2}, \mathrm{~N}_{3}$ and $\mathrm{N}_{4}$ were two, three and four-fold $\mathrm{N}_{1}$, respectively. Nitrogen was supplied in a $85 \%$ as calcium nitrate $\left(\mathrm{Ca}\left({ }^{15} \mathrm{NO}_{3}\right)_{2}\right)$ and the remaining $15 \%$ as potassium nitrate $\left(\mathrm{K}^{15} \mathrm{NO}_{3}\right)$, both with an isotopic enrichment of 5 atom $\%{ }^{15} \mathrm{~N}$, in a nutrient solution containing also other macro and micronutrients as in the first year of the assay. The use of ${ }^{15} \mathrm{~N}$ allows not only tracing the fertilizer $\mathrm{N}$ in the soil-plant system but also accurate quantifying fertilizer $\mathrm{N}$ uptake and NUE. With the aim of assessing $\mathrm{N}$ losses associated with abscised parts, tree litter (leaves of previous year, flowers, petals, calyces and fruitlets) was caught in nets from onset of flowering (1st April) until the end of fruit setting (4th July). Abscised organs were dried, weighed, milled and stored for subsequent 
analysis. In both experiments, the plants were watered using two drip emitters for each tree. The amount of water applied to each tree was equivalent to the total seasonal crop evapotranspiration (ETc; Doorenbos \& Pruitt, 1977). The volume of water applied weekly was calculated using the expression: $\mathrm{ETc}=\mathrm{ETo} \mathrm{x} \mathrm{Kc}$; where ETo is the reference crop evapotranspiration under standard conditions, determined using the Penman-Monteith approach (Allen et al., 1998), and Kc (crop coefficient) is a function of canopy size and leaf properties based on the guidelines provided by Castel and Buj (1994). The soil water potential was controlled daily using a ThetaProbe PR2 (Delta-T Devices, Cambridge, UK) and irrigation was scheduled when the matric potential at $30 \mathrm{~cm}$ depth attained $-10 \mathrm{kPa}$. Values of water supplied per tree and mean minimum and maximum temperatures in each period of both experiments are shown in Table 1.

Table 1. Mean minimum and maximum temperatures and average irrigation water per tree, at each phenological period along the experiment 1 and 2 .

\begin{tabular}{ccccccc}
\hline & \multicolumn{3}{c}{ Experiment 1 (2005) } & \multicolumn{3}{c}{ Experiment 2 (2006) } \\
& Flowering & Fruit set & Fruit growth & Flowering & Fruit set & Fruit growth \\
\hline Min. temperature $\left({ }^{\circ} \mathrm{C}\right)$ & 4.2 & 14.2 & 16.7 & 7.1 & 15.6 & 17.8 \\
Max. temperature $\left({ }^{\circ} \mathrm{C}\right)$ & 17.6 & 26.5 & 28.7 & 19.0 & 27.4 & 29.9 \\
Irrigation $\left(\mathrm{L} \cdot\right.$ tree $\left.^{-1}\right)$ & 51.1 & 232.5 & 294.2 & 72.5 & 251.2 & 310.6 \\
\hline
\end{tabular}

\subsection{Plant Harvesting and Sample Analysis}

In order to evaluate fertilizer $\mathrm{N}$ uptake, trees were cut down at the soil surface and separated into flowers/fruits, leaves and twigs of current year, leaves of previous years and trunk plus branches, at each harvest event. Roots were collected and sorted by hand (coarse roots and fine roots) after removing all soil contained in the growing pots. All fractions were weighed and sampled to quantify total dry biomass. Samples were washed in non ionic detergent solution followed by several rinses in deionised water, weighed, frozen into liquid nitrogen, freeze-dried (Lyoalfa, Telstar, Barcelona, Spain), dry-weighed and ground in a water refrigerated mill (IKA M 20 , IKA Labortechnik, Staufen, Germany) before analysis. Determinations of total $\mathrm{N}$ concentration and ${ }^{15} \mathrm{~N}$ abundance were performed with an Elemental Analyzer (NC 2500 Thermo Finnigan, Bremen, Germany) coupled to an Isotope Ratio Mass Spectrometer (Delta Plus, Thermo Finnigan, Bremen, Germany).

\subsection{Calculations}

Based on data of dry weight (DW, g) and total $\mathrm{N}$ concentration $(\mathrm{N} \%, \mathrm{w} / \mathrm{w})$ for each plant compartment, $\mathrm{N}$ content was calculated: $\mathrm{N}(\mathrm{g})=\mathrm{N} \% \cdot \mathrm{DW} \cdot 100^{-1}$. The ${ }^{15} \mathrm{~N}$ content per plant compartment was calculated as follows: ${ }^{15} \mathrm{~N}_{\text {plant compartment }}(\mathrm{mg})=\mathrm{N} \% \cdot \mathrm{DW} \cdot$ atom $\%{ }^{15} \mathrm{~N}$ excess $\cdot 10^{-1}$; where atom $\%{ }^{15} \mathrm{~N}$ excess was calculated by subtracting the natural abundance of ${ }^{15} \mathrm{~N}$ from the atom $\%{ }^{15} \mathrm{~N}$ in each sample. The natural abundance of ${ }^{15} \mathrm{~N}$ was considered to be the abundance of atmospheric $\mathrm{N}_{2}, 0.3663$ atom \%, according to the International Atomic Energy Agency (IAEA, 1983). The fraction $\mathrm{N}$ which is derived from the fertilizer (Ndff) was calculated according to Hardarson (1990): Ndff $(\%)=100 \cdot$ atom $\%{ }^{15} \mathrm{~N}$ excess plant compartment $/$ atom $\%{ }^{15} \mathrm{~N}$ excess fertilizer $_{\text {. Total plant recovery of }}$ applied ${ }^{15} \mathrm{~N}$-fertilizer represents the proportion of applied ${ }^{15} \mathrm{~N}$ that is taken up by the tree and embodies its fertilizer-nitrogen use efficiency (NUE). NUE was calculated by the formula: NUE $=100 \cdot{ }^{15} \mathrm{~N}$ taken up whole plant $(\mathrm{mg}) /{ }^{15} \mathrm{~N}_{\text {fertilizer }}(\mathrm{mg})$; where ${ }^{15} \mathrm{~N}$ taken up ${ }_{\text {whole plant }}(\mathrm{mg})=\Sigma^{15} \mathrm{~N}(\mathrm{mg})_{\text {plant compartment. A potential nitrogen leaching }}$ (PNL) index was introduced to quantify effects of $\mathrm{N}$ rates on $\mathrm{N}$ leaching and potential ground water contamination, with values defined as follows: PNL $=100$ - NUE for NUE $<100 \%$ (Scholberg et al., 2002).

\subsection{Statistical Analysis}

Data were subjected to ANOVA and means were separated by LSD test at the 0.05 level to determine the significance of differences among the $\mathrm{N}$ seasonal distributions within each harvest event, using SAS software (Statistical Analysis System Institute Inc., Cary, North Carolina, USA). Percentage values were transformed using the arc sin of the square root before statistical analysis. Statistical comparison of NUE between treatments was based on the total cumulative uptake at the end of the growing season divided by the total $\mathrm{N}$ supply. Correlation between $\mathrm{N}$ supply and logarithmic transformed NUE values were calculated; differences in the slopes and intercepts of the regressed lines were tested between periods by ANOVA. 


\section{Results and Discussion}

\subsection{Experiment 1}

Total biomass of trees increased steadily along the cycle (Table 1), with an overall increment of 2.8 -fold between dormancy and the beginning of fruit ripening harvest (15th October). Similar increases in total tree dry weight have been registered in young potted citrus trees (Martínez et al., 2002; Martínez-Alcántara et al., 2011; Quiñones et al., 2011), and slightly higher (3.1-fold) when grown in field (Menino et al., 2007). Highest increment in dry weight was registered during fruit growth period, mainly as a consequence of the rapid growth of fruits and the development of summer and autumn flushes (data not shown). Abscised organs (petals, ovaries/fruitlets and calyces) represented approximately $5 \%$ of total dry weight (data not shown) both at flowering and at fruit set; this value is in the range previously reported for young citrus trees (Legaz et al., 1982).

Table 2. Seasonal evolution of young potted citrus trees fed with a saturating $\mathrm{N}$ solution and harvested at the end of each period (experiment 1)

\begin{tabular}{|c|c|c|c|c|c|}
\hline & $\begin{array}{c}\text { Dormancy } \\
\left(1^{\text {st }} \mathrm{Jan}\right)\end{array}$ & $\begin{array}{c}\text { Flowering } \\
\left(15^{\text {th }} \mathrm{Jan}-15^{\text {th }} \mathrm{Jul}\right)\end{array}$ & $\begin{array}{c}\text { Fruit set } \\
\left(15^{\text {th }} \text { Apr- } 15^{\text {th }} \mathrm{Jul}\right)\end{array}$ & $\begin{array}{c}\text { Fruit growth } \\
\left(15^{\text {th }} \mathrm{Jul}-15^{\text {th }} \text { Oct }\right)\end{array}$ & ANOVA $^{Z}$ \\
\hline $\operatorname{Biomass}^{\mathrm{Y}}(\mathrm{g})$ & $761.8 \mathrm{c}$ & $895.8 b c$ & $1166.2 \mathrm{~b}$ & $2141.7 \mathrm{a}$ & $* * *(<0.001)$ \\
\hline $\mathrm{N}$ content ${ }^{\mathrm{Y}}(\mathrm{mg})$ & $14702.7 d$ & $16572.7 \mathrm{c}$ & $20291.9 b$ & $28261.3 \mathrm{a}$ & $* * *(<0.001)$ \\
\hline N uptake ${ }^{\mathrm{X}}(\mathrm{mg})$ & & $1870.0 \mathrm{c}$ & $3719.3 b$ & $7969.7 \mathrm{a}$ & $* * *(<0.001)$ \\
\hline $\mathrm{N}$ uptake rate ${ }^{\mathrm{W}}\left(\mathrm{mg} \mathrm{day}^{-1}\right)$ & & $20.3 \mathrm{c}$ & $40.9 \mathrm{~b}$ & $86.6 \mathrm{a}$ & $* * *(<0.001)$ \\
\hline
\end{tabular}

Z: Significant differences between harvest events are given at $p \leq 0.001(* * *)$. $p$-value between brackets (Fisher test); $\mathrm{n}=6$ trees. Y: Cumulative value at the harvest event, at the end of each period. $\mathrm{X}: \mathrm{N}$ uptake corresponds to the difference in total tree $\mathrm{N}$ content between consecutive harvest events. W: Average uptake rate within each period.

Nitrogen content (Table 2) in whole tree reached its maximum at the beginning of fruit ripening (15th Oct), when the initial $\mathrm{N}$ status (dormancy) was almost doubled. The $\mathrm{N}$ lost in senesced parts represented $12 \%$ and $3 \%$ of total tree $\mathrm{N}$ content at flowering and at fruit set harvests, respectively (data not shown). Nitrogen in abscised organs was computed in total content since, although not available for tree growth, also constitutes a sink of N.

Given the fact that plants were fed with a saturating $\mathrm{N}$ solution, difference in total tree $\mathrm{N}$ content within consecutive harvest events embodies plant $\mathrm{N}$ requirements along the phenological phase and represents $\mathrm{N}$ uptake during the period. According to this assumption, $\mathrm{N}$ requirements increased as the cycle progressed. Plant $\mathrm{N}$ budget increased $13 \%$ between dormancy and flowering; this increment in $\mathrm{N}$ content rose to $22 \%$ and $39 \%$ between subsequent periods, meaning that $\mathrm{N}$ needs were maximum during fruit growth period (Table 2). According to these data, average daily uptake rate of $\mathrm{N}$ significantly increased as the cycle progressed, reaching its highest value during the fruit growth period $\left(86.6 \mathrm{mg} \mathrm{N} \mathrm{day}^{-1}\right)$. These results are in line with previous studies which show that citrus trees take up proportionately more $\mathrm{N}$ during summer months (Kubota et al., 1976a \& 1976b; Legaz et al., 1995; Martínez-Alcántara et al., 2012).

Basing on the data of $\mathrm{N}$ uptake in the different phenological periods, $\mathrm{N}$ rates to be tested in experiment 2 were set (Table 3); thus $\mathrm{N}_{1}$ approximately equaled tree $\mathrm{N}$ uptake in each period of experiment 1, while $\mathrm{N}_{2}, \mathrm{~N}_{3}$ and $\mathrm{N}_{4}$ were two, three and four-fold $\mathrm{N}_{1}$, respectively.

Table 3. Fertilizer rates supplied to young containerized citrus trees in different phenological periods (experiment 2)

\begin{tabular}{ccrr}
\hline $\begin{array}{c}\text { N rate } \\
\left(\mathrm{mg} \cdot \text { tree }^{-1}\right)\end{array}$ & Flowering & Fruit set & Fruit growth \\
\hline $\mathrm{N}_{1}$ & 2000 & 4000 & 8000 \\
$\mathrm{~N}_{2}$ & 4000 & 8000 & 16000 \\
$\mathrm{~N}_{3}$ & 6000 & 12000 & 24000 \\
$\mathrm{~N}_{4}$ & 8000 & 16000 & 32000 \\
\hline
\end{tabular}




\subsection{Experiment 2}

\subsubsection{Tree Biomass}

Total tree biomass showed a similar pattern to that presented in the prior experiment, increasing along the year cycle (Table 4); average dry weight was regardless $\mathrm{N}$ rate, 36.7, 1042.5 and $2132.1 \mathrm{~g}$ at the end of flowering, fruit set and fruit growth periods, respectively. Total dry weight remained unaffected by $\mathrm{N}$ rate in all three periods: The lack of response of tree growth to differential $\mathrm{N}$ supply can be attributed not only to the shortness of each period, but also to the fact that enhanced remobilization partially counterbalanced the further diminished uptake of trees under low $\mathrm{N}$ supply (Martínez-Alcántara et al., 2011) mainly in the early stages, when reserve $\mathrm{N}$ plays its major role.

Table 4. Seasonal variation of total tree dry weight, $\mathrm{N}$ content and fertilizer $\mathrm{N}$ uptake according to different $\mathrm{N}$ rates $\left(\mathrm{N}_{1}, \mathrm{~N}_{2}, \mathrm{~N}_{3}\right.$ and $\left.\mathrm{N}_{4}\right)$ in young potted citrus trees

\begin{tabular}{|c|c|c|c|c|c|c|c|c|c|c|c|c|c|c|c|}
\hline \multirow[b]{2}{*}{ Nrate } & \multicolumn{4}{|c|}{ Flowering } & \multicolumn{4}{|c|}{ Fruit set } & \multicolumn{4}{|c|}{ Fruit growth } & \multicolumn{3}{|c|}{ ANOVA $^{Z}$} \\
\hline & $N_{1}$ & $\mathbf{N}_{2}$ & $\mathbf{N}_{3}$ & $\mathbf{N}_{4}$ & $\mathbf{N}_{1}$ & $\mathbf{N}_{2}$ & $\mathbf{N}_{3}$ & $\mathbf{N}_{4}$ & $\mathbf{N}_{1}$ & $\mathbf{N}_{2}$ & $\mathbf{N}_{3}$ & $\mathbf{N}_{4}$ & $\mathbf{N}$ & $\mathbf{P}$ & $\mathbf{N x P}$ \\
\hline $\operatorname{Biomass}^{Y}(\mathrm{~g})$ & $832.9 \mathrm{c}$ & $810.3 \mathrm{c}$ & $867.0 \mathrm{c}$ & $880.5 \mathrm{c}$ & $998.7 \mathrm{bc}$ & 1019.0bc & $1109.9 \mathrm{~b}$ & $1138.0 \mathrm{~b}$ & $2214.7 \mathrm{a}$ & $2131.8 \mathrm{a}$ & $2049.7 \mathrm{a}$ & $2100.9 \mathrm{a}$ & $\begin{array}{c}\text { NS } \\
(0.885)\end{array}$ & $\begin{array}{c}* * * \\
(0.000)\end{array}$ & $\begin{array}{c}\text { NS } \\
(0.387)\end{array}$ \\
\hline $\mathrm{Nuptake}^{\mathrm{X}, \mathrm{W}}(\mathrm{mg})$ & $1109.4 \mathrm{f}$ & 1419.6ef & $1844.9 \mathrm{e}$ & 2020.6e & $3133.2 \mathrm{~d}$ & $4237.3 \mathrm{dc}$ & $5080.8 \mathrm{c}$ & $5560.0 \mathrm{c}$ & $5367.1 \mathrm{c}$ & $8593.5 \mathrm{~b}$ & $11529.0 \mathrm{a}$ & $11701.8 \mathrm{a}$ & $\begin{array}{c}* * * * \\
(0.000)\end{array}$ & $\begin{array}{c}* * * \\
(0.000)\end{array}$ & $\begin{array}{c}* * \\
(0.015)\end{array}$ \\
\hline N content ${ }^{Y}$ (mg) & 13213.6e & $13479.0 \mathrm{e}$ & 14612.8de & 15227.3de & $16030.5 \mathrm{~d}$ & $17001.4 \mathrm{~d}$ & $19430.0 \mathrm{c}$ & $20257.3 \mathrm{c}$ & $24769.9 \mathrm{~b}$ & 26587.6ab & 27097.7a & 28315.6a & $\begin{array}{c}* \\
(0.033)\end{array}$ & $\begin{array}{c}* * * \\
(0.000)\end{array}$ & $\begin{array}{c}* \\
(0.024)\end{array}$ \\
\hline $\mathrm{Ndff}^{\mathrm{XV}}$ & $8.4 \mathrm{~g}$ & $10.5 \mathrm{fg}$ & $12.6 \mathrm{f}$ & $13.3 \mathrm{f}$ & $19.5 \mathrm{e}$ & $24.9 \mathrm{~cd}$ & $26.1 \mathrm{c}$ & $27.4 \mathrm{c}$ & $21.7 \mathrm{de}$ & $32.3 \mathrm{~b}$ & $42.5 \mathrm{a}$ & $41.3 \mathrm{a}$ & $\begin{array}{c}* * * \\
(0.000)\end{array}$ & $\begin{array}{c}* * * \\
(0.000)\end{array}$ & $\begin{array}{c}* \\
(0.040)\end{array}$ \\
\hline $\mathrm{NUE}^{\mathrm{X}, \mathrm{U}}$ & $55.5 \mathrm{c}$ & $35.5 \mathrm{f}$ & $30.7 \mathrm{~g}$ & $25.3 \mathrm{~h}$ & $78.3 \mathrm{a}$ & $53.0 \mathrm{c}$ & $42.3 \mathrm{e}$ & $34.8 \mathrm{f}$ & $67.1 \mathrm{~b}$ & $53.7 \mathrm{c}$ & $48.0 \mathrm{~d}$ & $36.3 \mathrm{f}$ & $\begin{array}{c}* * * \\
(0.000)\end{array}$ & $\begin{array}{c}* * * \\
(0.000)\end{array}$ & $\begin{array}{c}* * * \\
(0.000)\end{array}$ \\
\hline
\end{tabular}

Z: Significant effects of $\mathrm{N}$ rate $\left(\mathrm{N}_{1}, \mathrm{~N}_{2}, \mathrm{~N}_{3}\right.$ and $\left.\mathrm{N}_{4}\right)$, phenological period (P: flowering, fruit set and fruit growth) and its interaction (NxP) are given at $p>0.05$ (NS, not significant), $p \leq 0.05(*), p \leq 0.01(* *)$ and $p \leq 0.001$ (***) at each harvest event. $p$-values (Fisher test) are given between brackets; $\mathrm{n}=6$ trees. Y and X: see table 1 . W: N uptake $(\mathrm{mg})=\Sigma\left[\left(\mathrm{N}(\%, \mathrm{w} / \mathrm{w}) \cdot \mathrm{DW}(\mathrm{g}) \cdot\right.\right.$ atom $\%{ }^{15} \mathrm{~N}$ excess $\left.\cdot 10\right) /\left(\right.$ atom $\left.\left.\%{ }^{15} \mathrm{Nfertilizer}\right)\right]$ plant compartments. V: Ndff (\%) $=\left(100 \cdot\right.$ atom $\%{ }^{15} \mathrm{~N}$ excess plant compartment $) /\left(\right.$ atom $\left.\%{ }^{15} \mathrm{~N}_{\text {fertilizer }}\right)$. U: NUE $(\%)=100 \cdot{ }^{15} \mathrm{~N}$ taken up whole plant $(\mathrm{mg}) /$ ${ }^{15} \mathrm{~N}_{\text {fertilizer }}(\mathrm{mg})$.

\subsubsection{N content: Seasonal N Uptake}

Fertilizer $\mathrm{N}$ uptake clearly differed among periods, being the lowest values recorded at flowering while increased significantly later on at fruit set and fruit growth periods (Table 4). As a consequence of the enhanced $\mathrm{N}$ uptake, whole tree $\mathrm{N}$ budget increased significantly as the cycle progressed. However, the response to differential $\mathrm{N}$ rates depended on the phenological period. At flowering and at fruit set $\mathrm{N}$ uptake slightly increased between $\mathrm{N}_{1}$ and $\mathrm{N}_{2}$, reaching a plateau from $\mathrm{N}_{2}$ onwards; however, during fruit growth, tree $\mathrm{N}$ uptake sharply increased until $\mathrm{N}_{3}$ rate, remaining constant with $\mathrm{N}_{4}$ (Figure 1). This uptake pattern is a consequence of the finite capacity of trees to use available soil $\mathrm{N}$ and the capacity to self-regulate net $\mathrm{N}$ uptake once that capacity has been met (Youssefi et al., 2000). Increased fertilizer $\mathrm{N}$ uptake with highest $\mathrm{N}$ rates significantly raised total tree $\mathrm{N}$ content at fruit set and fruit growth (Table 4), whereas no response was found at flowering harvest, when differences in fertilizer $\mathrm{N}$ uptake were buffered as a consequence of its small contribution to the total tree $\mathrm{N}$ pool in this period, which remained almost constant. The diminished root activity during the early stages of growth (Davies \& Albrigo, 1994) i.e. between dormancy and flowering, would have been responsible for the even $\mathrm{N}$ uptake at all rates tested during these months, resulting in a scarce response in $\mathrm{N}$ content. According to $\mathrm{N}$ rates tested in each period, significantly lower concentrations were found in trees fertilized with $\mathrm{N}_{1}$ rates when compared to highest rates. 


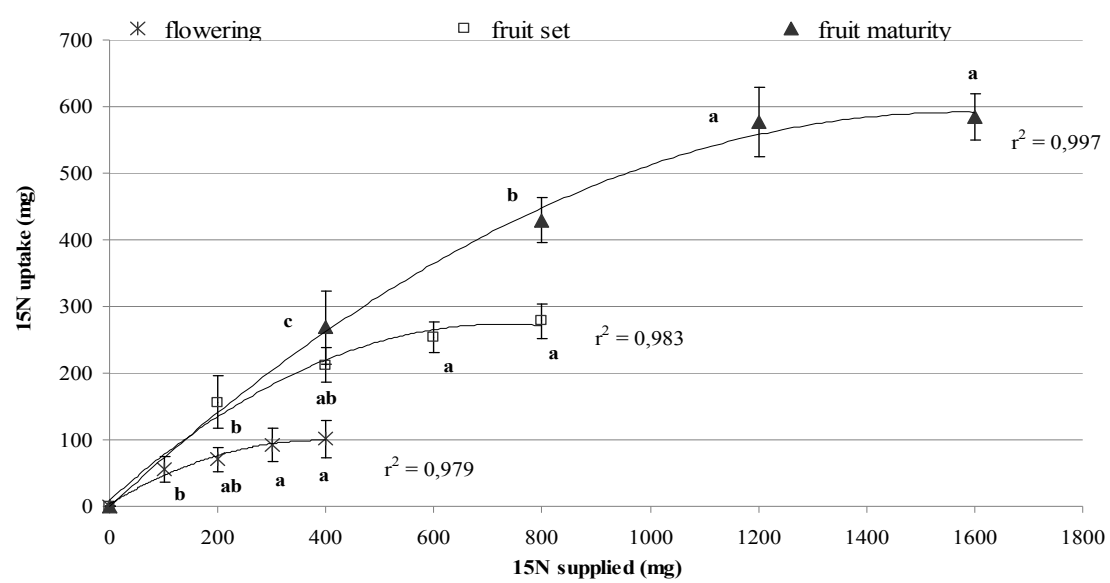

Figure 1. Fertilizer $\mathrm{N}$ uptake response to differential $\mathrm{N}$ supply at three phenological periods (flowering, fruit set and fruit growth) of young citrus trees

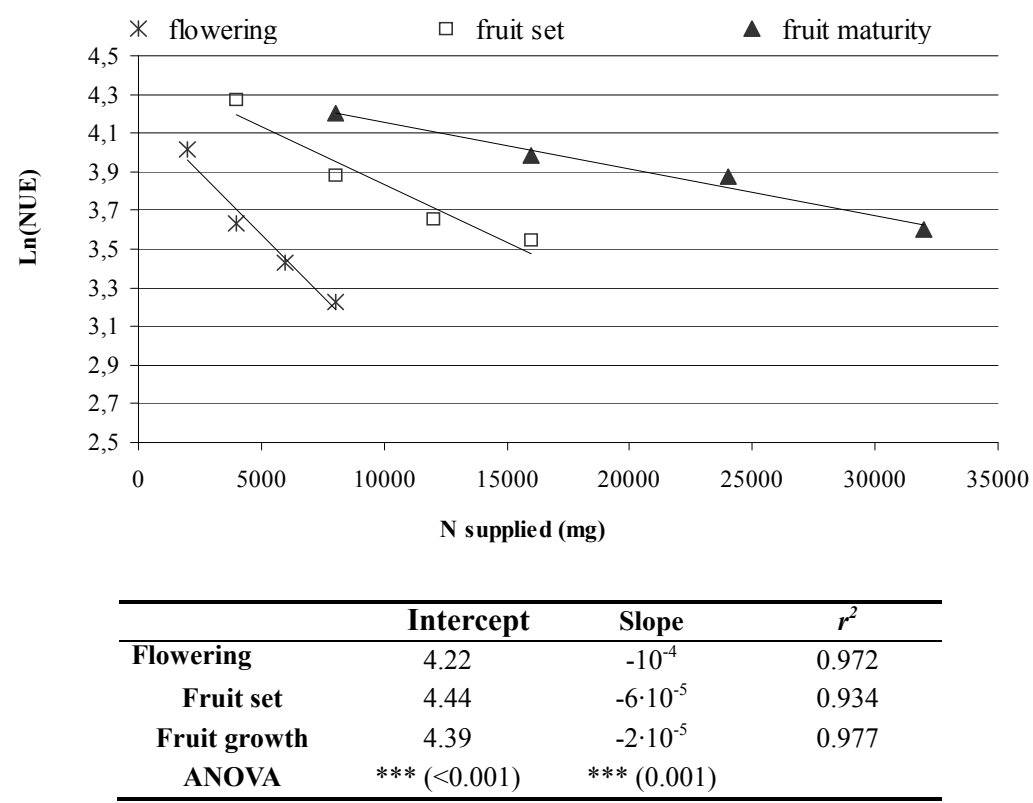

Figure 2. Correlation between logarithm of NUE and N rate at three phenological periods (flowering, fruit set and fruit growth), values of linear regression intercept, slope and correlation coefficients $\left(r^{2}\right)$, and their statistical comparison

\subsubsection{Nitrogen Derived from Fertilizer}

Nitrogen derived from fertilizer (Ndff), that is, the relative contribution of fertilizer $\mathrm{N}$ to the total content of this element in plant organs, increased along the cycle. Ndff ranged between $8-13 \%$ during flowering, while these percentages rose to $19-27 \%$ and $22-41 \%$ at the end of fruit set and fruit growth periods, respectively, indicating the increased relative contribution of fertilizer $\mathrm{N}$ to the total plant $\mathrm{N}$ pool (Table 4). The low percentage of Ndff at flowering period confirms earlier observations, which stress that in early spring, when conditions for root uptake are not conducive, $\mathrm{N}$ is absorbed to a lesser extent and thus fruit trees (Titus \& Kang, 1982; Millard, 1996), and hence of course citrus (Legaz et al., 1995), mainly rely on $\mathrm{N}$ remobilization for flower development and spring flush. Lower $\mathrm{N}$ rates led to minor Ndff values in all periods; the diminished Ndff is associated to higher remobilization of stored $\mathrm{N}$, since the amount of $\mathrm{N}$ remobilized by young citrus plants depends on external $\mathrm{N}$ availability (Martínez-Alcántara et al., 2011).

\subsubsection{Fertilizer N Uptake Efficiency: Seasonal Variation}

The percentages of applied $\mathrm{N}$ actually recovered in plant organs (NUE) regardless $\mathrm{N}$ rate were minimum at flowering (55-25\%), while similar ranges were obtained at fruit set (78-35\%) and fruit growth $(67-36 \%)$ (Table 4). For a given $\mathrm{N}$ rate, NUE was lowest at flowering, increasing later on at fruit set and fruit growth periods; (e.g. $\mathrm{N}$ supply of $8,000 \mathrm{mg}$, which corresponds to $\mathrm{N}_{4}, \mathrm{~N}_{2}$ and $\mathrm{N}_{1}$ at flowering, fruit set and fruit maturity, respectively, 
resulted in a NUE of 25, 53 and $67 \%$, respectively). Moreover, increasing $\mathrm{N}$ rate within each phenological period undoubtedly decreased NUE (Table 4) since rates exceeding citrus N-requirements result in lower NUE (Lea-Cox et al., 2001; Syvertsen \& Smith 1996), while on the contrary, plants grown under N-limiting conditions may have a greater affinity and capacity for N uptake resulting in higher NUE (Dasberg, 1987; Rufty et al., 1990). The logarithm of NUE linearly correlated with $\mathrm{N}$ rate at each phenological period; the slope of regression lines was significantly higher at flowering, which indicates the scarce response in $\mathrm{N}$ uptake when increasing $\mathrm{N}$ supply at early stages, thus resulting in an abrupt decrease in NUE. Slopes of correlation lines decreased later on, being the smoothest slope obtained at fruit growth period, as a result of the enhanced fertilizer $\mathrm{N}$ uptake in summer months when root system of the citrus trees is highly effective in taking up the $\mathrm{N}$ applied (Davies \& Albrigo, 1994; Kubota et al., 1976a, 1976b; Scholberg et al., 2002). These results corroborate previous findings on the higher NUE when fertilizer was supplied on June (61\%; Kubota et al., 1976b) if compared to earlier application on March (25\%; Kubota et al., 1976a). In this sense Martínez-Alcántara et al. (2012) also obtained higher NUE in summer, when compared to times of the year when trees are not actively growing.

\subsubsection{N Supply and NUE Prediction}

Data on fertilizer $\mathrm{N}$ uptake under increasing $\mathrm{N}$ rates allowed establishing regression equations between both parameters at the three phenological periods (Figure 3 and Table 5). The equations were used to calculate the amount of the fertilizer $\mathrm{N}$ to be supplied in order to fulfill tree specific requirements at each period, that is, $1870.1,3719.3$ and $7969.7 \mathrm{mg} \mathrm{N}$ for flowering, fruit set and fruit growth periods, respectively (set in experiment 1). According to these correlations, fertilizer $\mathrm{N}$ supply should be increased 3.5, 1.4 and 1.7-fold to ensure that trees uptake the appropriate (Table 5). In this way, theoretical NUE can be hence calculated; the greatest NUE value would be obtained at the end of fruit set period (72\%); whereas minimum NUE (28\%) would be attained at flowering period, when potential nitrogen leaching will therefore reach its maximum (71\%). Reported values of NUE for lysimeter-grown citrus trees in Florida were on the order of 61 to $68 \%$ (Syvertsen \& Smith, 1996). Nevertheless, it is worth mentioning that the most remarkable of the results presented is the comparison between NUE response to differential $\mathrm{N}$ rates according to the phenological period, rather than the NUE-specific values themselves that obviously would change according to experimental conditions i.e. $\mathrm{N}$ rates tested, soil type, and other environmental factors such as temperature.

Table 5. Theoretical prediction of fertilizer $\mathrm{N}$ supply, $\mathrm{N}$ uptake efficiency (NUE) and potential $\mathrm{N}$ leaching (PNL) according to $\mathrm{N}$ requirements $\left(\mathrm{N}_{\mathrm{r}}\right)$ in young citrus trees at different phenological periods (flowering, fruit set and fruit growth). Values in $\mathrm{a}, \mathrm{b}$ and $\mathrm{c}$ columns represent the quadratic coefficients in the regression equations between $\mathrm{N}$ uptake $\left(\mathrm{N}_{\mathrm{u}}\right)$ and supply $\left(\mathrm{N}_{\mathrm{s}}\right)$ : $\mathrm{N}_{\mathrm{s}}=\mathrm{a} \cdot \mathrm{N}_{\mathrm{u}}{ }^{2}+\mathrm{b} \cdot \mathrm{N}_{\mathrm{u}}+\mathrm{c}$

\begin{tabular}{lrrrrrrrr}
\hline & $\mathrm{a}$ & $\mathrm{b}$ & \multicolumn{1}{c}{$\mathrm{c}$} & $\mathrm{r}^{2}$ & $\mathrm{~N}_{\mathrm{r}}(\mathrm{mg})$ & $\mathrm{N}_{\mathrm{s}}(\mathrm{mg})^{\mathrm{Z}}$ & $\mathrm{NUE}^{\mathrm{Y}}$ & $\mathrm{PNL}^{\mathrm{X}}$ \\
\hline Flowering & $3 \cdot 10^{-4}$ & 6.59 & -6820.8 & 0.935 & 1870.0 & 6559.8 & $28.5 \mathrm{c}$ & 71.5 \\
Fruit set & $1.1 \cdot 10^{-3}$ & -5.05 & 8734.6 & 0.996 & 3719.3 & 5150.8 & $72.2 \mathrm{a}$ & 27.8 \\
Fruit growth & $3 \cdot 10^{-4}$ & -1.74 & 9046.3 & 0.920 & 7969.7 & 14209.1 & $56.1 \mathrm{~b}$ & 43.9 \\
\hline
\end{tabular}

$Z$ : Ns values are calculated considering that $\mathrm{N}_{\mathrm{u}}$ equals $\mathrm{N}_{\mathrm{r}}$. $\mathrm{Y}$ : NUE $=\mathrm{N}_{\mathrm{r}} / \mathrm{N}_{\mathrm{s}}$. $(\mathrm{n}=6$ trees)

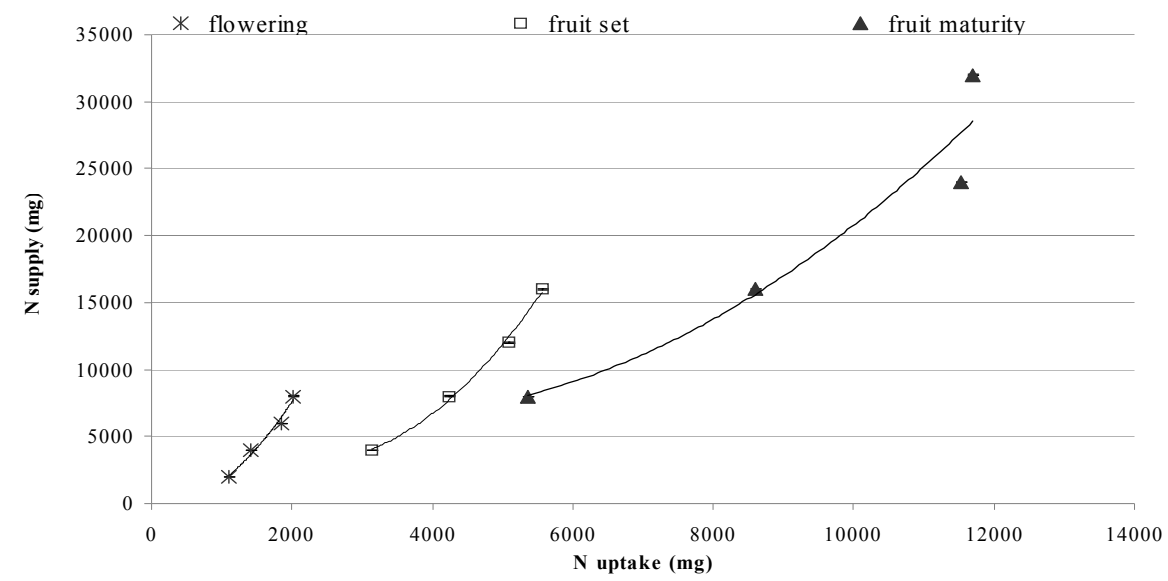

Figure 3. Correlation between $\mathrm{N}$ uptake and $\mathrm{N}$ supplied in young citrus trees at three phenological periods (flowering, fruit set and fruit growth) 


\section{References}

Agustí, M., Zaragoza, S., Bleiholder, H., Buhr, L., Hack, H., Klose, R., \& Stauss R. (1997). Adaptation de l'échelle à la description des stades phénologiques des agrumes du genre Citrus. Fruits, 52, 287-295.

Allen, R. G., Pereira, L. S., Raies, D., \& Smith, M. (1998). Crop evapotranspiration (guidelines for computing crop water requirements) FAO Irrigation and Drainage Paper, No. 56, FAO, Rome.

Alva, A., \& Paramasivam, S. (1998). Nitrogen management for high yield and quality of citrus in sandy soils. Soil Sci. Soc. Am. J., 62, 1335-1342. http://dx.doi.org/10.2136/sssaj1998.03615995006200050027x

Alva, A. K., Paramasivam, S., Graham, W. D., \& Wheaton, T. A. (2003). Best nitrogen and irrigation management practices for citrus production in sandy soils. Water Air Soil Pollution, 143(1-4), 139-154. http://dx.doi.org/10.1023/A:1022883311070

Alva, A. K., Paramasivam, S., Obreza, T. A., \& Schumann, A. W. (2006). Nitrogen best management practice for citrus trees II. Nitrogen fate, transport, and components of N budget. Sci. Hort., 109(3), 223-233.

Boman, B. J., Gunter, D. E. Jr., \& Futch, S. H. (2004). Best Management Practices for Citrus Groves in the Peace River and Manasota Basins. Publication No. 5M-5.005.10.04. Florida Department of Agriculture and Consumer Services. Tallahassee. Florida.

Castel, J. R., \& Buj, A. C. (1994). Growth and evapotranspirationof young drip-irigated clementine trees. In: Proc. Int. Soc. Citriculture. VII International Citrus Congress (1992), vol. 2. Acireale, Sicily (Italy), pp. 651-656.

Dasberg, S. (1987). Nitrogen fertilization in citrus orchards. Plant Soil, 100, 1-9. http://dx.doi.org/10.1007/BF02370928

Davies, F. S., \& Albrigo, L. G. (1994). Citrus. CAB International, Wallingford, UK. p. 254.

Doorenbos, J., \& Pruitt, W. O. (1977). Crop water requirements. FAO Irrigation and Drainage Paper, No. 24, FAO, Rome.

EEA, European Environment Agency. (2003). Europe's Water: An indicator-based assessment. Topic report 1/2003. EEA, Copenhagen, 97 pp. [Online] Available: http://www.eea.europa.eu/publications/topic_report_2003_1. (26th December 2011)

Hack, H., Bleiholder, H., Buhr, L., Meier, U., Schnock-Fricke, U., Stauss, R., Weber, E., \& Witzenberger, A. (1992). Einheitliche Codierung der phänologischen Entwicklungsstadien mono- und dikotyler Pflanzen. Erweiterte BBCH-Skala. Allgemein -.Nachrichtenbl. Deut. Pflanzenschutzd, 44(12), 265-270.

Hardarson, G. (1990). Use of nuclear techniques in studies of soil-plant relationships. (Training Course Series 2) Vienna, IAEA, p. 223.

Hodge, A., Robinson, D., \& Fitter, A. (2000). Are microorganisms more effective than plants at competing for nitrogen? Trends in Plant Science, 5, 304-308. http://dx.doi.org/10.1016/S1360-1385(00)01656-3

IAEA, International Atomic Energy Agency. (1983). A guide to the use of nitrogen-15 and radioisotopes in studies of plant nutrition: calculations and interpretation of data. Vienna.

Kato, T., Kubota, S., \& Tsukahara, S. (1981). ${ }^{15} \mathrm{~N}$ absorption and translocation in Satsuma trees. VI. Uptake and distribution of nitrogen supplied in summer. Bull. Shikoku Agric. Exp. Stn., 36, 1-6.

Kubota, S., Kato, T., Akao, S., \& Bunya, C. (1976a). ${ }^{15} \mathrm{~N}$ absorption and translocation in Satsuma trees III. Behaviour of nitrogen supplied in early spring. Bull. Shikoku Agric. Exp. Stn., 29, $49-54$.

Kubota, S., Kato, T., Akao, S., \& Bunya, C. (1976b). ${ }^{15} \mathrm{~N}$ absorption and translocation in Satsuma trees IV. Behaviour of nitrogen supplied in early summer. Bull. Shikoku Agric. Exp. Stn., 29, 55-56.

Lea-Cox, J. D., \& Syvertsen, J. P. (1996). How nitrogen supply affects growth and nitrogen uptake, use efficiency, and loss from Citrus seedlings. J. Am. Soc. Hort. Sci., 121(1), 105-114.

Lea-Cox, J. D., Syvertsen, J. P., \& Graetz, D. A. (2001). Springtime ${ }^{15}$ Nitrogen uptake, partitioning, and leaching losses from young bearing Citrus trees of differing nitrogen status. J. Amer. Soc. Hort. Sci., 126(2), 242-251.

Legaz, F., Primo-Millo, E., Primo-Yúfera, E., Gil, C., \& Rubio, L. (1982). Nitrogen fertilization in citrus. Absorption and distribution of nitrogen in calamondin trees (Citrus mitis B1.), during flowering, fruit set and initial fruit development periods. Plant Soil, 66(3), 339-351. http://dx.doi.org/10.1007/BF02183800

Legaz, F., Serna, M. D., \& Primo-Millo, E. (1995). Mobilization of the reserve N in citrus. Plant Soil, 173, 205-210. http://dx.doi.org/10.1007/BF00011457 
Martínez, J. M., Bañuls, J., Quiñones, A., Martín, B., Primo-Millo, E., \& Legaz, F. (2002). Fate and transformation of ${ }^{15} \mathrm{~N}$ labelled applied in spring to Citrus trees. J. Hortic. Sci. Biotech, 77(3), 361-367.

Martínez-Alcántara, B., Quiñones, A., Primo-Millo, E., \& Legaz, F. (2011). Nitrogen remobilization response to current supply in young citrus trees. Plant Soil, 342, 433-443. http://dx.doi.org/10.1007/s11104-010-0707-5

Martínez-Alcántara, B., Quiñones, A., Primo-Millo, E., \& Legaz, F. (2012). Nitrogen-use efficiency of young citrus trees as influenced by timing of fertilizer application J. Plant Nutr. Soil Sci. (in press).

Masclaux-Daubresse, C., Daniel-Vedele, F., Dechorgnat, J., Chardon ,F., Gaufichon, L., \& Suzuki, A. (2010). Nitrogen uptake, assimilation and remobilization in plants: challenges for sustainable and productive agriculture. Ann Bot, 105(7), 1141-1157. http://dx.doi.org/10.1093/aob/mcq028

Maust, B. E., \& Williamson, J. G. (1994). Nitrogen nutrition of containerized citrus nursery plants. J. Amer. Soc. Hort. Sci., 119(2), 195-201.

McNeal, B. L., Stanley, C. D., Espinoza, L. A., \& Schipper, L. A. (1994). Nitrogen management for vegetables and citrus: some environmental considerations. Soil and Crop Sci. Soc. Fla. Proc., 53, 45-51.

Menino, M. R., Carranca, C., \& de Varennes, A. (2007). Distribution and remobilization of nitrogen in young non-bearing orange trees grown under mediterranean conditions. J. Plant Nutr., 30, 1083-1096. http://dx.doi.org/10.1080/01904160701394543

Millard, P. (1996). Ecophysiology of the internal cycling of nitrogen for tree growth. Z Pflanzenernähr Bodenk, 159(1), 1-10.

Quiñones, A., Bañuls, E., Primo-Millo, E., \& Legaz, F. (2003). Effects of ${ }^{15} \mathrm{~N}$ application frequency on nitrogen uptake efficiency in citrus trees. J. Plant Physiol., 160, 1429-1434. http://dx.doi.org/10.1078/0176-1617-01018

Quiñones, A., Bañuls, E., Primo-Millo, E., \& Legaz, F. (2005). Recovery of the ${ }^{15} \mathrm{~N}$-labelled fertiliser in citrus trees in relation with timing of application and irrigation system. Plant Soil, 268, 367-376. http://dx.doi.org/10.1007/s11104-004-0337-x

Quiñones, A., Martínez-Alcántara, B., Martínez, J. M, Forner-Giner, M. A., Iglesias, D. J., Primo-Millo, E., \& Legaz, F. (2011). Fate of ${ }^{15} \mathrm{~N}$ labelled potassium nitrate in different citrus cultivated soils: influence of spring and summer application. Water Air Soil Pollut. http://dx.doi.org/10.1007/s11270-011-1017-0

Rufty, T. W., MacKown, C. T., \& Volk, R. J. (1990). Alterations in nitrogen assimilation and partitioning in nitrogen stressed plants. Physiol. Plant, 79, 85-95. http://dx.doi.org/10.1111/j.1399-3054.1990.tb05870.x

Scholberg, J. M. S, Parsons, L. R., Wheaton, T. A., Morgan, K. T., \& McNeal, B. L. (2002). Soil temperature, N concentration, and residence time affect nitrogen uptake efficiency of citrus. J. Env. Qual., 31, 759-768. http://dx.doi.org/10.2134/jeq2002.0759

Stassen, P. J. C., Mostert, P. G., \& Smith, B. L. (1999). Mango tree nutrition. A crop perspective. Scientiae, 303, 41-51.

Syvertsen, J. P., \& Smith, M. L. (1996). Nitrogen uptake efficiency and leaching losses from lysimeter-grown Citrus trees fertilized at three nitrogen rates. J. Am. Soc. Hort. Sci., 121(1), 57-62.

Titus, J. S., \& Kang, S. (1982). Nitrogen metabolism, translocation and recycling in apple trees. Hortic. Rev., 4, 204-246.

Tucker, D. P. H, Alva, A. K., Jackson, L. K., \& Wheaton, T. A. (eds.). (1995). Nutrition of Florida citrus trees. SP-169. Univ. Fla., Gainesville. p. 61.

Weinbaum, S. A., Brown, P. H., Rosecrance, R. C., Picchioni, G. A., Niederholzer, F. J. A., Youseffi, F., \& Muraoka, T. T. (2001). Necessity for whole tree excavations in determining patterns and magnitude of macronutrient uptake by mature deciduous fruit trees. Acta Hort., 564, 41-49.

Weinbaum, S. A., Johnson, R. S., \& Dejong, T. M. (1992). Causes and consequences of over fertilization in orchards. J. Amer. Soc. Hort. Sci., 2, 112-121.

WHO, World Health Organization. (2004). Guidelines for drinking water quality. In Recommendations, vol. 1, $3^{\text {rd }}$ edition. WHO, Geneva.

Youssefi, F., Weinbaum, S. A., \& Brown, P. H. (2000). Regulation of nitrogen partitioning in field-grown almond trees: effects of fruit load and foliar nitrogen applications. Plant Soil, 227, 273-281. http://dx.doi.org/10.1023/A:1026572615441 